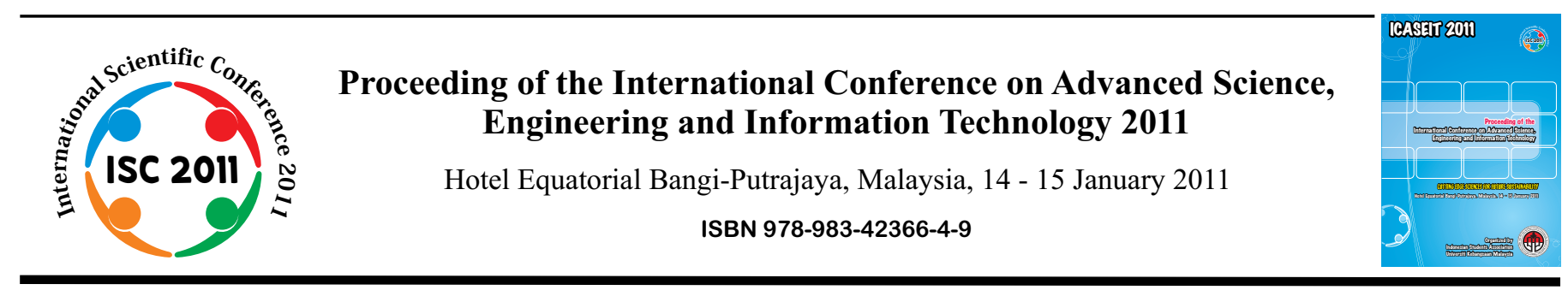

\title{
Assessing the Effects of Construction Delays on MARA Large Projects
}

\author{
Aftab Hameed Memon ", Ismail Abdul Rahman *, Mohd Razaki Abdullah*, Ade Asmi Abdul Azis \# \\ \# University Tun Hussein Onn Malaysia (UTHM) \\ 86400 Parit Raja, Batu Pahat, Johor, Malaysia \\ Tel.:+60142725620,E-mail:ah78memon@hotmail.com \\ *Majlis Amanah Rakyat (MARA), Malaysia \\ Tel.:+60-12-7876360,E-mail:abdullahrazaki@gmail.com
}

\begin{abstract}
Construction industry in Malaysia is facing a serious issue of construction delay causing a significant amount of time over run and cost over run. Various studies have addressed the issue of construction delay, however, most of studies focused on identifying causes of delay. Less attention has been paid of assessing effects of construction delay. Hence this study is aimed to assess effects of construction delay on MARA large projects. Investigation approach for study includes the site study of 30 MARA large projects selected from various areas of Malaysia and structured questionnaire survey among client, consultant and contractor personnel's. It is important to note that $\mathbf{9 0 \%}$ of MARA projects are experiencing time overrun. Data was analyzed with statistical analysis to calculate rank of the effects of delays and correlation with spearman formula to identify the interrelationship between attributes of effects. Results showed that time over-run and cost over-run are most significant effects of delay on MARA construction projects. Time over-run has high degree of correlation with cost over-run and moderate degree of correlation with disputes.
\end{abstract}

Keywords - Construction Delay, Effects of Delay

\section{INTRODUCTION}

Construction industry plays a vital role in economic growth of Malaysia. The industry is facing a lot of challenges such as the delay to complete the project in time, the expenditure exceeding the budget, the building defects and over dependent of foreign workers [1]. MARA (Majlis Amanah Rakyat) is one of the government agencies of Malaysia that plays important role in implementing the government policy and was formed on March 1, 1966 under the Rural and National Development Ministry [http://maranet.mara.gov.my/Am/sejarah_mara_dari_rida_ke _mara.htm]. It is currently placed under the Rural and Regional Development Ministry after briefly controlled by the Entrepreneur and Co-operation Development Ministry. MARA has spent about RM 12 billion in its development since 1st Malaysian plan [2]. A portion of this allocation was spent on construction. The major issue in MARA large construction project is the delay in completing its projects. An interview with Tech Art Executive Director revealed that more that $90 \%$ of large MARA construction project experienced delay since 1984. The impact of this delay largely contributed to the deceleration of the implementation of MARA strategic planning. MARA has its own construction unit, Construction and maintenance unit (UBS) to manage the small project but engage PMC service for its large and complex construction project. This paper focus large construction projects only. It is difficult to define large constructions. In as study of Vietnam projects with a total budget of $\$ 1$ million were considered as large projects [3]. However, in this study a project of budget RM 5 million and above is considered as large construction project.

\section{LITERATURE REVIEW}

\section{A. Construction Delay}

Construction industry is regarded as a complex, fragmented and schedule \& resource driven industry. A successful project is achieved if it is completed on time, within budget and to the specified quality standards [4]. Timely completion of a project is as a major criterion of project success ([5], [6]).

Delays in construction industry are defined in many ways. It refers to progress compared to baseline construction schedule. Baseline construction schedule refers to the 
schedule prepared by contractor before the start of the project and approved by the client. Although delay to progress does not necessarily end up to project delay but most of the time this progress delay leads to project delay.

"Reference [7] claimed that a delay is an event or a condition that results in work activity starting, or project completion, later than originally planned or an interruption or a hindrance to a planned program”. He also stressed that this delay may result in delay claims such as time extension, monetary compensation or both. Basically his interpretation of delay seems to refer to project delay. "Reference [8] seems to agree with [3] that they concluded that delay is the time overrun either beyond completion date specified in a contract, or beyond the date that the parties agreed upon for delivery of a project". The element of extension of time in completing the project is clearly seen as the main effect of the delay. Delay is an act or event that extends the time required to perform the tasks under a contract [9]. Again, his view seems to agree with both [7], [8], where his interpretation of delay largely refers to project delay.

Clearly, most of the definition associates delay with extension of time to the project. Therefore a delay in construction industry can be classified into construction delay and project delay. Construction delay refers to delay in construction progress while project delay refers to delay to the duration of the project. The fact that construction delay does not necessarily end in project delay, but construction delay is certain if there is project delay. No doubt, project delay can be either due to late start, late progress and late finish or the combination of those situations.

\section{B. Effects of Construction Delay}

Effect is a change [10]. Certainly, the 'change' refers to the effect that might be surfaced due to the impact of the delay in construction projects. These effects can be very costly to all construction parties particularly clients and contractors. Time overrun, cost overrun, disputes, arbitration, litigation and total abandonment are the possible effects of construction delay [11].

The delay of construction project for whatever reasons, most probably lead to time overrun as the project may experience extension of time. This extension of time also may lead to cost overrun where it involves extra financial expenditure. Dispute is another effect of the delay where most of the time is between contractor and client as it involves claims. Many times, arbitration is preferred to solve the dispute as it can satisfy all parties to a certain extent. If there is a deadlock, litigation is the last measure to be taken by all parties. Not many researchers studied on the effect of the delay.

"Reference [11] studied and evaluated the effects of construction delays on project delivery in Nigerian construction industry and found that the six effects of construction delay were: time overrun, cost overrun, dispute, arbitration and litigation and total abandonment”. Time overrun and cost overrun are the two most significant effect of delay in Malaysian construction projects [12].

The incidence of disputes is another common effect of construction delay. This dispute is normally between contractors and clients and it significantly affects the progress of construction projects. To minimize this dispute, [13] recommended the use of schedule as contract document. In addition to that, a fair and effective evaluation of delay impact is possible if the most appropriate delay analysis method is selected [14]. Arbitration, litigation and total abandonment seem to be the least frequent effects of construction delay.

In essence, literature shows that time overrun is the most frequent effects of construction delay ([11], [12], [15]-[17]). The next most frequent seem to be cost overrun ([11], [12], [17]). Disputes, arbitration, litigation and total abandonment seem to be the least frequent effects of construction delay. Countries such as Hong Kong, Ghana, Vietnam, Nigeria and Malaysia seem to share the common effect of construction delay, i.e. time overrun. On the contrary, [18] investigated 31 high-rise projects to study and concluded in Indonesia cost overruns occur more frequently and are more severe problem than time overruns.

\section{DATA COLLECTION AND ANALYSIS}

The study was carried out in two phase. In first phase 30 MARA Large projects were considered to study the effects of construction delays. In second phase of study, structured questionnaire survey was carried out amongst the client, Project Management Consultant (PMC) and contractor personnel's. A five point likert-scale of 1 to 5 was adopted to assess the degree of agreement of each effect where 1 represented 'strongly disagree', 2 'disagree', 3 'moderately agree’, 4 'agree’ and 5 ‘strongly agree’. Data was analysed by using Statistical Package for Social Sciences (SPSS). Method of data analysis was selected from the decision flow chart as given in figure 1 .

\section{A. Ranking of Delay Effects}

The ranking of effects of construction delays is calculated based on the mean score and standard deviation.

\section{B. Correlation}

The strength of associations of pairs of variables understudy is determined by correlation relationships. The 3 commonly used methods for ascertaining the strength of association between 2 variables is the Pearson correlation method, the Spearman rank correlation method and the Chi square test of independence method. As data collected in this study is non-parametric and ordinal variables, the powerful method of examining the relationship between pairs of variables is by using Spearman's Rank Order Correlation [19].

$$
\text { The formula for Spearman } \rho=1-\frac{6 \sum d^{2}}{n\left(n^{2}-1\right)}
$$

Where $\mathrm{d}$ is the difference between ranks and $\mathrm{n}$ is the highest weight.

The correlation coefficient (or " $\rho$ ") ranges from -1.0 to +1.0 . The closer $\rho$ is to +1 or -1 , the more closely the two variables are related. The value of $\rho$ close to 1 implies there is strong positive linear relationship between the two variables while the value of $\rho$ close to -1 is a strong negative linear relationship between the two variables [20]. Ideally, the correlation coefficient value of \pm 1 is said to be a perfect correlation. Assume correlation coefficient value lies between \pm 0.5 and \pm 1 , then it is said to be a high degree of 
correlation and for the correlation coefficient value lies between \pm 0.3 and \pm 0.5 , then it is said to be moderate degree of correlation. If correlation coefficient value lies between \pm 0.1 and \pm 0.3 then it is said to be a low degree of correlation and suppose correlation coefficient value lies around zero, then there is no correlation [21].

\section{RESULTS AND DISCUSSION}

\section{A. Effects of Construction Delay}

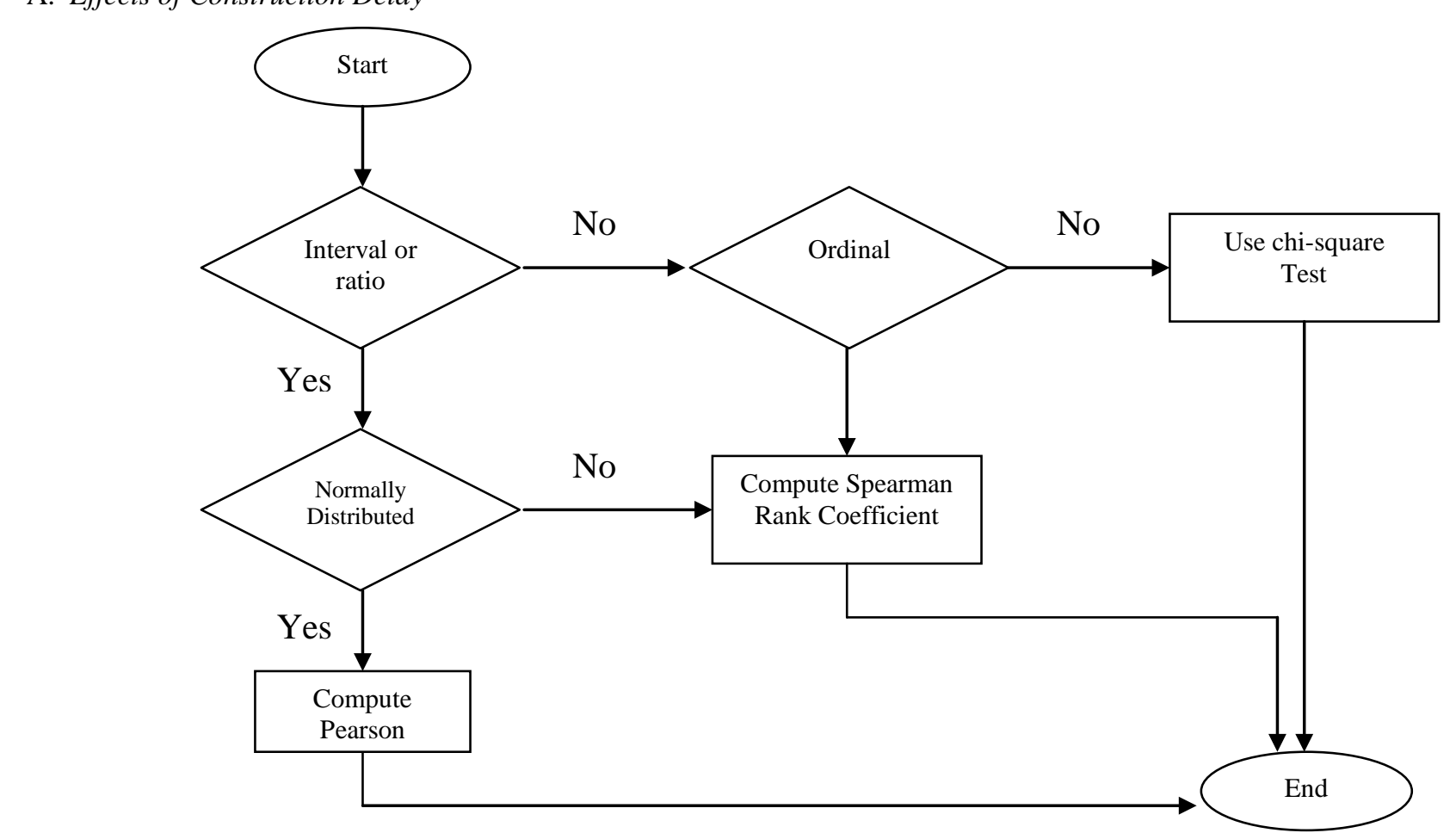

Fig. 1 Decision Flowchart for Choice of Method in Association Problem

TABLE I

List of Projects FACING Time OverRun EFFeCtS

\begin{tabular}{|c|c|c|c|c|c|}
\hline S.No & Name of Project & $\begin{array}{l}\text { Project Cost } \\
\text { (Million RM) }\end{array}$ & $\begin{array}{c}\text { Project } \\
\text { Duration } \\
\text { (days) }\end{array}$ & $\begin{array}{c}\text { Time } \\
\text { Overrun } \\
\text { (Days) }\end{array}$ & $\begin{array}{l}\text { \% Time } \\
\text { Overrun }\end{array}$ \\
\hline & PERAK & & & & \\
\hline 1 & Pembinaan MRSM Kroh, & 33.6 & 504 & 335 & 66.47 \\
\hline 2 & Pembinaan MRSM Kuala Kangsar, Perak & 40.3 & 545 & 4 & 0.73 \\
\hline 3 & Pembesaran/Peningkatan IKM Lumut, Perak. & 11.2 & 700 & 35 & 5.00 \\
\hline 4 & Pembinaan KKTM Lenggong, Perak. & 113.3 & 791 & 21 & 2.65 \\
\hline \multirow[t]{2}{*}{5} & Pemasangan Slipway Winh System, MIMET & 1.3 & 265 & 68 & 25.66 \\
\hline & SELANGOR & & & & \\
\hline 6 & Bina MRSM Tanjung Karang, Selangor & 47.9 & 503 & 326 & 64.81 \\
\hline 7 & Bina Kampus Baru GMI & 333.2 & 910 & 7 & 0.77 \\
\hline 8 & Pembesaran MFI, Bangi & 13.0 & 545 & 194 & 35.60 \\
\hline 9 & Bengkel Kimpalan MSI, Kulim & 1.8 & 168 & 76 & 45.24 \\
\hline \multirow[t]{2}{*}{10} & Cadangan pembangunan FDRC di Fitec & 1.6 & 84 & 2 & 2.38 \\
\hline & PAHANG & & & & \\
\hline 11 & Bina MRSM Pekan, Pahang & 48.5 & 671 & 153 & 22.80 \\
\hline 12 & Pembinaan MRSM Bentong, Pahang. & 55.0 & 504 & 76 & 15.08 \\
\hline 13 & Menambahbaik MRSM Kuala Lipis. & 3.6 & 349 & 4 & 1.15 \\
\hline \multirow[t]{2}{*}{14} & KKTM Kuantan, Pahang & 66.4 & 728 & 256 & 35.16 \\
\hline & TERENGGANU & & & & \\
\hline
\end{tabular}

Table 1 shows the List of Projects faced by Time Over run problem in various states of Malaysia considered for current study. From above table it is observed that out of 30 projects 17 (56.67\%) projects were caused by 1-100 days time overrun, 5 (16.67\%) projects in between 101 to 200 days, 5 (16.67\%) projects 201 to 300 days whereas 3 (10\%) projects were delayed for time period above 300 days as shown in figure 2.$$
\text { . }
$$ 


\begin{tabular}{|c|c|c|c|c|c|}
\hline 15 & Peningkatan Fasa 2 MRSM Kuala Terengganu & 2.8 & 279 & 332 & 119.00 \\
\hline 16 & Bina IKM Kemaman, Terengganu & 67.0 & 713 & 18 & 2.52 \\
\hline \multirow[t]{2}{*}{17} & Membina 1 Unit Banglo PMN Terengganu & 0.3 & 219 & 84 & 38.36 \\
\hline & SARAWAK & & & & \\
\hline 18 & Pembinaan MRSM Betong, Sarawak. & 42.6 & 728 & 34 & 4.67 \\
\hline \multirow[t]{2}{*}{19} & Pembinaan MRSM Mukah, Sarawak & 48.0 & 727 & 203 & 27.92 \\
\hline & NEGERI SEMBILAN & & & & \\
\hline \multirow[t]{2}{*}{20} & Pembesaran MRSM Kuala Klawang, Negeri Sembilan. & 13.0 & 909 & 66 & 7.26 \\
\hline & KELANTAN & & & & \\
\hline \multirow[t]{2}{*}{21} & Pembinaan MRSM Tumpat, Kelantan & 48.7 & 538 & 127 & 23.61 \\
\hline & PERLIS & & & & \\
\hline \multirow[t]{2}{*}{22} & Pembinaan MRSM Arau, Perlis & 38.6 & 727 & 241 & 33.15 \\
\hline & SABAH & & & & \\
\hline \multirow[t]{2}{*}{23} & Pembinaan MRSM Sandakan, Sabah & 87.5 & 700 & 31 & 4.43 \\
\hline & MELAKA & & & & \\
\hline 24 & Pembesaran/Peningkatan IKM Jasin, Melaka. & 47.0 & 364 & 138 & 37.91 \\
\hline \multirow[t]{2}{*}{25} & Bina Kolej Profesional MARA Tiang Dua, & 29.8 & 504 & 213 & 42.26 \\
\hline & JOHOR & & & & \\
\hline 26 & Bina IKM Sri Gading, Johor. & 72.9 & 511 & 273 & 53.42 \\
\hline 27 & Pembesaran IKM Johor Bharu, Johor. & 9.4 & 413 & 263 & 63.68 \\
\hline 28 & Pembinaan IKM Muar, Johor. & 64.3 & 728 & 55 & 7.55 \\
\hline 29 & Pembinaan Institut Latihan dan Kecemerlangan MARA & 33.1 & 279 & 76 & 27.24 \\
\hline 30 & Kompleks Inkubator Teknologi Makanan Kepong & 9.4 & 349 & 77 & 22.06 \\
\hline
\end{tabular}

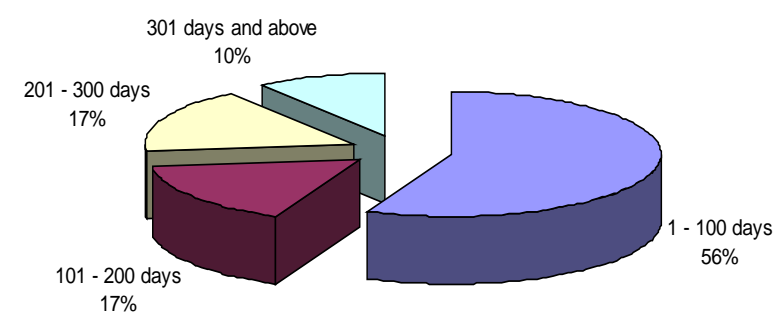

Fig. 1 \% Project Delayed Based on Time overrun in Day

In order to calculate the rank of effects of construction delays, data was analyzed by calculating mean and standard deviation. Table 2 shows the ranking of effects of construction delays on these projects.

Based on the analysis in Table 2, time overrun and cost overrun are rated extremely high by all respondents. Time overrun is very significant effect of delay while cost overrun is significant effect of delay. However, Disputes, Arbitration, litigation and total abandonment are $3^{\text {rd }}$, 4rth, $5^{\text {th }}$ and $6^{\text {th }}$ rank scoring as reported by clients. Whereas, consultant's responses show that arbitration is $3^{\text {rd }}$ significant score and disputes, total abandonment and litigation are 4rth, $5^{\text {th }}$ and $6^{\text {th }}$ rank scoring effects. According to contractors arbitration was $3^{\text {rd }}$ effects and disputes, litigation and total abandonment are ranked as $4 \mathrm{rth}, 5^{\text {th }}$ and $6^{\text {th }}$ ranked effects. Overall, time overrun is $1^{\text {st }}$, cost overrun $2^{\text {nd }}$, arbitration, disputes, total abandonment are ranked as $3^{\text {rd }}, 4 \mathrm{rth}, 5^{\text {th }}$ and litigation as least scoring effect.

1) Time Overrun: Time overrun is ranked extremely high by all respondents. No doubt it is the most significant effect of the construction delay in MARA projects. It is observed that the time overrun is closely associated with cost overrun. Most of the time, as the delay involves the extension of time to the project life and this may lead to cost overrun, as expenditure increases due to increase of time. This time overrun also has the multiplying effects to client where MARA has to reprogram its strategic planning. During projects study it was observed that more than $90 \%$ MARA projects were experiencing time overrun. This crucial situation forced MARA to re-schedule its training activities resulting potential trainees lost the opportunities to be trained.

2) Cost Overrun: Cost overrun is ranked second to time overrun. It is highly rated by all respondents and eventually become one of significant effect of the construction delay. Time overrun is closely related to cost overrun and most of the time leads to cost overrun. The severity of cost overrun is depended on the length of the time overrun. During projects study, it was observed that payment for salaries, utility bills and fluctuation of material prices are some of expenditure that have to be borne that may contribute to cost overrun. The situation will be worsening if the contractors were terminated; new contractors were hired with significant increase in prices. The cost overrun can be due to contractor's poor site management, escalation of material prices and ineffective planning and scheduling by contractors.

3) Arbitration: Arbitration is also moderately rated by all respondents. It is used if both parties fail to solve the disputes amicably. Certainly, a third party or an arbitrator which is highly respected by both parties is appointed be the middle man to facilitate the disputes. Most of the time, arbitration is used when the client is terminating the contractor's contract where the completed work by the contractor is to be evaluated and compensated. Mean score indicates that the degree of frequency of arbitration is quite moderate compared to time overrun and cost overrun.

4) Dispute: Dispute is moderately rated by all respondents as its score is quite moderate compared to time overrun and cost overrun. This moderate score shows that 
respondents apparently view disputes are quite frequent to a certain extent. Most of the time, the dispute or disagreement is between contractor and client where the dispute may involves claims for compensation, liquidated damages and extension of time. The classification into types of delay significantly diffuses the disputes as it is spelt out in the agreement. Most of the time, other parties such as consultants' opinion are taken into account to solve the dispute. Project studies showed that low speed of decision making by client, escalation of material prices, changes in scope of projects during construction work, frequent design changes and client interference may contribute to dispute.
5) Total Abandonment: The results show that the degree of frequency of total abandonment is quite moderate. Apparently, contractors try very hard to avoid the total abandonment in their projects as this effect hurts the reputation of the contractors and subsequently will be blacklisted.

6) Litigation: Litigation is lowly rated by all respondents. This indicates that all parties use litigation as their last choice. This litigation is also very rare in MARA management procurement construction project as all parties try to avoid the high cost and the long length of time during the litigation. Client's interference and termination of the project may lead to litigation.

TABLE II

RANKING OF EFFECTS OF CONSTRUCTION DELAY

\begin{tabular}{|c|c|c|c|c|c|c|c|c|c|c|c|c|}
\hline \multirow{2}{*}{ Effect of Delay } & \multicolumn{3}{|c|}{ All Respondents } & \multicolumn{3}{|c|}{ Clients } & \multicolumn{3}{|c|}{ Consultants } & \multicolumn{3}{|c|}{ Contractors } \\
\hline & Mean & S.D & Rank & Mean & S.D & Rank & Mean & S.D & Rank & Mean & S.D & Rank \\
\hline Time Overrun & 4.52 & 0.73 & 1 & 4.62 & 0.74 & 1 & 4.43 & 0.80 & 1 & 4.60 & 0.51 & 1 \\
\hline Cost Overrun & 4.25 & 0.81 & 2 & 4.14 & 0.85 & 2 & 4.24 & 0.76 & 2 & 4.4 & 0.91 & 2 \\
\hline Arbitration & 3.75 & 0.95 & 3 & 3.57 & 0.60 & 4 & 3.79 & 1.10 & 3 & 3.93 & 0.96 & 3 \\
\hline Disputes & 3.63 & 1.00 & 4 & 4.05 & 0.97 & 3 & 3.46 & 0.90 & 4 & 3.47 & 1.19 & 4 \\
\hline Total Abandonment & 3.20 & 1.09 & 5 & 3.43 & 1.03 & 6 & 3.46 & 1.02 & 5 & 2.27 & 0.88 & 6 \\
\hline Litigation & 3.15 & 0.95 & 6 & 3.52 & 0.75 & 5 & 3.14 & 0.92 & 6 & 2.67 & 1.11 & 5 \\
\hline
\end{tabular}

TABLE III

CORRELATION OF EFFECTS OF DELAY

\begin{tabular}{|l|l|l|l|l|l|l|}
\hline & Time Overrun & Cost Overrun & Arbitration & Disputes & $\begin{array}{l}\text { Total } \\
\text { Abandonment }\end{array}$ & Litigation \\
\hline Time Overrun & 1.000 & $0.614^{* *}$ & -0.590 & $0.428^{* *}$ & 0.093 & -0.350 \\
\hline Cost Overrun & $0.614^{* *}$ & 1.000 & 0.006 & $0.553^{* *}$ & 0.162 & 0.153 \\
\hline Arbitration & 0.059 & 0.006 & 1.000 & -0.029 & 0.090 & 0.202 \\
\hline Disputes & $0.428^{* *}$ & $0.553^{* *}$ & -0.029 & 1.000 & 0.186 & $0.366^{* *}$ \\
\hline Total Abandonment & 0.093 & 0.162 & 0.090 & 0.186 & 1.000 & $0.360^{* *}$ \\
\hline Litigation & 0.035 & 0.153 & 0.202 & $0.366^{* *}$ & 0.360 & 1.000 \\
\hline
\end{tabular}

\section{B. Relationship Between Effects of Delay}

As data collected through survey is based on Likertscale, it is non-parametric and ordinal variables. The powerful method of examining the relationship between pairs of variables is by using Spearman's Rank Order Correlation [19]. The correlation analysis of effect of delay is shown as in Table 3.

Based on Table 3, time overrun has high degree of correlation with cost overrun and moderate degree of correlation with disputes. While cost overrun has high degree of correlation with time overruns and moderate degree of correlation with disputes. Besides that, dispute has moderate degree of correlation with time overrun, cost overruns and Litigation and finally litigation has moderate correlation with disputes. The complete summary of correlation of effect of delay is shown in Table 4.

\section{Significant Effects of Delay}

Construction time, although only a part of the lifecycleduration of buildings, has become an increasingly important concern within the construction industry.

Furthermore, construction time is a basis for evaluating the success of a project and the efficiency of the project organization. Basically, no parties purposely want to delay the project. The time is so precious and all parties try very hard to avoid the delay. Contractors used to claim that the time overruns is due to excusable delay and the client sees differently.

TABLE IV

SUMMARY OF CORRELATION OF EFFECTS OF DELAY

\begin{tabular}{|l|l|l|}
\hline $\begin{array}{l}\text { The Effects of } \\
\text { Delay }\end{array}$ & $\begin{array}{l}\text { Highly Degree } \\
\text { of Correlation }\end{array}$ & $\begin{array}{l}\text { Moderately Degree } \\
\text { of Correlation } \\
\text { Highly }\end{array}$ \\
\hline Time overrun & Cost overrun & Disputes \\
\hline Cost overrun & Time overrun & Disputes \\
\hline Arbitration & Nil & Nil \\
\hline Dispute & Nil & $\begin{array}{l}\text { Cost overrun } \\
\text { Time overrun } \\
\text { Litigation }\end{array}$ \\
\hline Total Abandonment & Nil & Litigation \\
\hline Litigation & Nil & Disputes \\
\hline
\end{tabular}

Time overruns is concluded as the highest potential effect of the construction delay in MARA management procurement projects. More than $90 \%$ of its projects experienced time overruns where more than 30\% suffered time overruns for more than 200 days. This 'disturbing' situation effectively disrupts the implementation of MARA strategic planning. Cash flow and financial difficulties faced by contractors, contractors' poor site management 
and ineffective planning and scheduling by contractors are the potential cause of delay that may contribute to time overrun.

Cost overrun referred to excess of actual cost over budget. Most of the time, the risk of cost overrun is faced by contractor and client. The contractor has to bear extra cost such as wages, bills and penalties due to extension of time of the project. In client's case, extra cost is significantly seen if the present contract is terminated and a new contract is signed. In UBS report on 30th June 2008, it was shown that the initial project cost of the construction of 'Kolej Professional MARA Tiang Dua' was RM 24.87 million but as a new contract was signed, the project cost ballooned to RM 29.82 million, an increase of about RM 4.95 million or $19.90 \%$ compared to initial cost. The similar situation can be seen in the construction of 'Extension of IKM Jasin' when the initial cost was RM 4.65 million (new contract: RM 9.95 millidn,4\%), 'MRSM Arau' initial cost was RM 38.60 million (new contract: RM55.10 millio(442.75\%), However, cost escalation and increases do not necessarily result in cost overruns if cost escalation is included in the budget. Figure 3 shows the relation ship between time over run and cost over run.

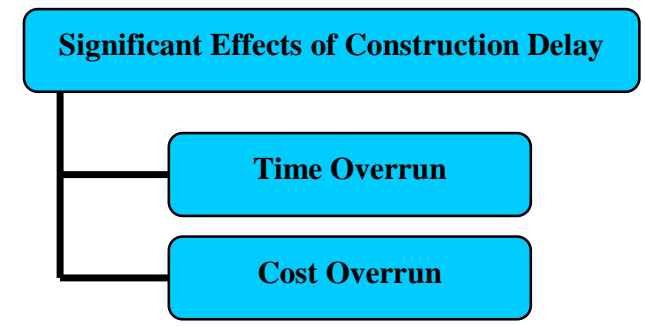

Fig. 3a Hierarchy Relationship of Significant Effects of Construction Delay

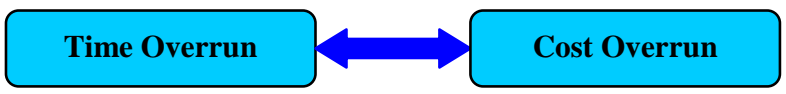

Fig. 3b Correlation of a pair of Variable of Effect of Delay

Figure 3a indicates the hierarchical relationship of significant effects of construction delays. Figure $3 \mathrm{~b}$ shows the correlation of a pair of significant effects of delay. Keeping all other variables constant, this time overrun has strong influence to cost overrun. Apparently, the extension of time of the project will increase the cost of the project.

\section{CONCLUSIONS}

MARA is one of government agencies in Malaysia which has spent high amount in construction development. MARA projects are facing a very serious problem to construction delay. Study revealed that $90 \%$ of MARA projects are experiencing construction delays. Construction delays result with six effects on project including (i) time overrun; (ii) cost overrun; (iii) arbitration; (iv) dispute; (v) total abandonment and (vi) Litigation. Study revealed time over-run and cost over-run are most significant effects of delay on any construction projects. Also results show that time over-run has high degree of correlation with cost overrun and moderate degree of correlation with disputes. Time over-run is found as attribute having strong linear relationship with each other.

\section{ACKNOWLEDGMENT}

We would like to thank University Tun Hussein Onn Malaysia for supporting this study. Also we are thankful to MARA official for providing comprehensive and important information and a lot of cooperation which made data collection easier.

\section{REFERENCES}

[1] CIDB news, issue 3, 2007

[2] http://maranet.mara.gov.my/Am/sejarah_mara_dari_rida_ke_marah tm

[3] L. Le-Hoai, Y. D. Lee, and J. Y. Lee, "Delay and cost overruns in Vietnam large construction projects: A comparison with other selected countries,” KSCE journal of civil engineering, Vol. 12(6), pp. 367-377, 2008

[4] D. W. M Chan, and M. M. Kumaraswamy "A Survey of time-cost relationship in Hong Kong construction projects" Building Technology and Management Journal, Building Technology Society, School of Technology, Tunku Abdul Rahman College, Kuala Lumpur, Malaysia, Vol. 20, pp. 54-72, 1993-1994.

[5] NEDO, Faster Building For Commerce HMSO, UK, 1988

[6] P. D. Rwelamilla, K. A. Hall, "Total systems intervention: an integrated approach to time, cost and quality management," Construction Management and Economics, Volume 13(3), pp. 235 - 241, May 1995.

[7] S. Mubarak, Construction Project Scheduling and Control, Pearson Prentice Hall, 2005

[8] S. Assaf, and S. Al-Hejji, "Causes of delay in large construction projects in Saudi Arabia” International Journal of project management, Vol. 24(4), pp. 349-57, 2006.

[9] G. Stumpf, "Schedule delay analysis,” Cost Eng Journal, Vol. 42 (7), pp. 32-43, 2000

[10] Longman, Longman Essential Activator, Pearson Education, 1997

[11] A. A. Aibinu, and G. O. "The effects of construction delays on project delivery in Nigerian construction industry” International Journal of Project management, Vo. 20, pp. 593-599, 2002.

[12] M. Sambasivan, and Y. W. Soon, "Causes and effects of delays in Malaysian construction industry," International Journal of project management, Vol. 25, pp. 517-526, 2007

[13] J. Conlin, and A. Retik, "The applicability of project management software and advanced IT techniques in construction delays mitigation,” International Journal of project management, Vol. 15(2), pp. 107-120, 1997

[14] D. Arditi, and T. Pattanakitchamroon "Selecting a delay method in resolving construction claims," International Journal of project management, Vol. 24 (4), pp. 145-155, 2006

[15] D. W. M. Chan and M. M. Kumaraswamy, "A comparative study of causes of time overruns in Hong Kong construction projects" International Journal of Project management, Vol. 15(1), pp. 55-63, 1997

[16] Y. Frimpong, J. Oluwoye, and L. Crawford L, “Causes of delay and cost overruns in construction of groundwater projects in a developing countries: Ghana as a case study,” International Journal of Project management Vol. 21, 2003

[17] N. D. Long, S. Ogunlana, T. Quang, and K. C. Lam, “ The delay of large construction projects in developing countries : a case study from Vietnam” International Journal of project management, Vol. 22, pp. 553-561, 2004

[18] P. Kaming, P. Olomolaiye, G. Holt, and F. Harris, "Factors influencing construction time and cost overruns on high-rise projects in Indonesia," Construction Management and Economics, Vol. 15, pp. 83-94, 1997

[19] A. Bryman, and D. Cramer D, Quantative Data Analysis with SPSS Release 10 for Windows, 2nd edition, Taylor and Francis inc. 2002

[20] Z. M. Daud, M. H. Ahmad, and F. Yusof, Elementary Statistics, Preatice Hall, Pearson (M) Sdn. Bhd, 2009

[21] J. Cohen, Statistical power analysis for the behavioral sciences, 2nd ed., 1988 